\title{
Reprezentacje gender w polskiej sferze publicznej - próba uchwycenia dynamiki dyskursu ${ }^{* *}$
}

\section{KEYWORDS}

gender, hate speech, tolerance, discrimination, homophobia, sexism, anti-discrimination actions, politics

\begin{abstract}
Grochalska Monika, Reprezentacje gender w polskiej sferze publicznej - próba uchwycenia dynamiki dyskursu [Gender representations in the Polish public space - an attempt to capture the dynamics of the discourse]. Kultura - Społeczeństwo - Edukacja nr 1(17) 2020, Poznań 2020, s. 339-367, Adam Mickiewicz University Press. ISSN 2300-0422. DOI 10.14746/kse.2020.17.14.1
\end{abstract}

Before 2013, the term 'gender' as used to define male and female social roles had appeared relatively rarely in the public sphere. However, it had not been completely unknown. Whenever this term did occur in utterances of public figures, it was mostly in reference to equality policies (gender policy) and the idea of gender mainstreaming in EU projects. It was commonly associated with feminism and has in this form entered the social consciousness, including the minds of major public figures, especially those with highest state positions. The situation changed radically in 2013. The term 'gender' started to be connected with 'gender ideology', a term coined by people associated with the Catholic Church. This article presents the ways in which the issues related to the broadly meant gender are presented on the right and left sides of the political scene. This analysis is based on selected interviews and other utterances of famous politicians as well as the articles in popular weekly magazines published in 2011-2015. This paper covers both kinds of utterances - those in line with the rules of political correctness and the examples of hate speech. All examples are provided to highlight the mechanisms of discrimination hidden in the language of politics.

* ORCID https://orcid.org/0000-0003-2942-3309.

** Artykuł powstał w ramach projektu sfinansowanego ze środków Narodowego Centrum Nauki przyznanych na podstawie decyzji numer DEC-2011/01/D/HS6/02470. 


\section{Gender i dyskurs publiczny - ramy teoretyczne}

Przez kwestie związane z kulturową tożsamością płci zazwyczaj w świadomości społecznej w Polsce rozumie się prawa kobiet, ich obecność w polityce, prawa reprodukcyjne, przemoc domową, nierówne dochody, molestowanie seksualne oraz prawa osób homoseksualnych. Są to kwestie trudne, niejednoznaczne, kontrowersyjne, gdyż nieodłącznie związane ze światopoglądem, a jednocześnie domagają się uregulowań prawnych i politycznego dookreślenia, gdyż dotyczą całych grup społecznych. Nic dziwnego, że stosunkowo często pojawiają się te kwestie w wypowiedziach polityków i innych osób zajmujących znaczące pozycje w przestrzeni publicznej. Przykłady takich wypowiedzi, wybranych do zaprezentowanej tu analizy, pochodzą z lat 2011-2015. Kwestie związane z gender zostały przedstawione $\mathrm{w}$ postaci różnych reprezentacji płci społeczno-kulturowej w dyskursie publicznym. Reprezentacje społeczne są trudnym przedmiotem badań ze względu na płynność procesu społecznego tworzenia wiedzy, a także na dynamikę oraz charakter samych reprezentacji. Są one zmienne, mają nieostre granice, zmieniają się płynnie lub dość gwałtownie, nie ma stałych reguł, które rządziłyby tymi przemianami. Decydują o nich jedynie działające w danym momencie siły pola dyskursu publicznego (Moscovici, 2000).

Szczególnie interesujące są analizy tej dynamiki w odniesieniu do nowych kategorii w obiegu społecznym - koncepcji lub obiektów, które nie mają jeszcze ustalonego znaczenia. Takim pojęciem jeszcze kilka lat temu było gender.

Zgodnie z definicją Serge’a Moscoviciego (Moscovici, 2000: 30) reprezentacje są jedną z form wiedzy potocznej i fundamentem komunikacji interpersonalnej. Zawarta w nich wiedza wypełnia sferę publiczną, nadaje jej sens, spójność, porządkuje, nadaje znaczenie poszczególnym jej fragmentom. Wiedza zawarta $\mathrm{w}$ reprezentacjach stanowi warunek konieczny zaistnienia komunikacji. Jeśli odnieść to do reprezentacji płci społeczno-kulturowej, można odnotować kilka różnych kontekstów odczytywania pojęcia gender. Są one związane z odmiennymi interpretacjami dokonywanymi przez różne grupy społeczne w zależności od ich tożsamości, przekonań (w tym politycznych), wyznawanych wartości, wiary, wizji przeszłości i przyszłości, życiowych celów. Teorie pojawiające się w kontekście gender są historycznie zmienne, co wiąże się ze zmiennością warunków społecznych, w których płeć społeczno-kulturowa jest „odgrywana”. Nawet na przestrzeni kilku lat widać wyraźne zmiany w tym zakresie. Niniejszy tekst jest próbą zobrazowania tychże przemian w dyskursie publicznym w Polsce. Został napisany na bazie koncepcji krytycznej analizy dyskursu (KAD) politycznego Teuna Van Dijka (Van Dijk, 2001: 352-358). 
W tym ujęciu krytyczna analiza dyskursu jest jednym z typów badań nad ustanawianiem i reprodukcją relacji władzy, przemocy, dominacji i nierówności poprzez tekst i mowę w określonym kontekście społeczno-politycznym. Tego typu badania koncentrują się wokół pojęcia kontroli - pewne grupy mają więcej bądź mniej władzy wówczas, gdy mogą w większym bądź mniejszym stopniu kontrolować działania i myśli członków innych grup. To podejście często nazywane jest koncepcją elit symbolicznych. Powstała ona pod dużym wpływem socjologicznych koncepcji Pierre’a Bourdieu. Według Van Dijka do elit symbolicznych danego społeczeństwa należą eksperci, publicyści, dziennikarze, redaktorzy, pisarze, autorzy podręczników szkolnych, duchowni, naukowcy, ludzie biznesu, intelektualiści, a także występujący w środkach masowego przekazu politycy. Są to osoby i grupy mające bezpośredni wpływ na kształt dyskursu publicznego. Elity symboliczne decydują o hierarchii spraw ważnych i nieważnych, o obowiązujących wartościach moralnych i estetycznych, a nawet o wzorcach recepcji stanowisk naukowych. Ich domeną jest władza w sferze symbolicznej, a także kulturowo-normatywna kontrola nad dyskursem publicznym. To elity decydują, co jest przedmiotem publicznej dyskusji i wpływają na przemiany tak zwanego dyskursu dominującego (Czyżewski, Franczak, Nowicka, Stachowiak, 2014: 7-20).

Władza daje uprzywilejowaną pozycję $\mathrm{w}$ dostępie do limitowanych dóbr społecznych, takich jak siła, pieniądze, status, sława, wiedza, informacja, kultura, a w istocie też do różnorodnych form dyskursu publicznego i możliwości komunikacji. Różne rodzaje władzy mają oparcie w różnych zasobach, które są wykorzystywane do jej sprawowania. I tak, władza wojskowa polega na sile fizycznej i potędze militarnej, władza bogatych opiera się na sile sprawczej pieniądza, władza rodzicielska lub nauczycielska bazuje na wiedzy, informacji czy też autorytecie. Warto jednak zauważyć, że rzadko jest to władza absolutna. Jedne grupy mogą kontrolować inne w mniejszym lub większym stopniu, zwykle tylko w pewnych ściśle określonych warunkach lub obszarach społecznych interakcji. Grupy zdominowane mogą wykazywać przy tym mniejszy lub większy opór - wachlarz możliwych reakcji rozpościera się od akceptacji poprzez przystosowanie się, aż po uzasadnianie władzy i uznawanie za "naturalną". Władza dominujących grup może być zawarta w prawie, zasadach, regulaminach, normach, zwyczajach. Często owa władza nie uwidacznia się w otwarcie opresyjnych działaniach, lecz jest ukryta w szeregu codziennych zachowań uznawanych za „pewnik”, niepodważalny społeczny fakt. Należy przy tym do grup, nie do jednostek - niejednokrotnie wybrane jednostki z grupy dominującej w pojedynkę są dużo słabsze od niektórych jednostek pochodzących z grup zdominowanych. Im bardziej wpływowy 
dyskurs kontroluje dana grupa, tym ma więcej okazji i możliwości kontrolowania myśli i zachowań innych ludzi (Van Dijk, 2001: 352-358). Przy czym ważny jest też kontekst, który, jak definiuje go Van Dijk, nie jest jedynie pewnym typem środowiska społecznego, sytuacji czy struktury społecznej. Jest raczej subiektywną psychiczną reprezentacją, dynamicznym modelem, który w danym momencie podzielają uczestnicy sytuacji komunikacyjnej. Jest to mentalna „definicja sytuacji” (zespół dyspozycji), która umożliwia kontrolowanie procesu wytwarzania i rozumienia dyskursu w danym środowisku, na danym społecznym gruncie (Van Dijk, 2009: 66).

Dyskurs publiczny to przekazy, które powstają w różnego rodzaju dyskursach instytucjonalnych, funkcjonują w ramach różnych światów społecznych. Przekazy dyskursywne docierają do szerokiego grona odbiorców za pośrednictwem mediów. Na dyskurs medialny składają się: przekazy telewizyjne, prasowe i internetowe. Jednak ze względu na sferę, do której się odnoszą, można w jego ramach wyróżnić między innymi dyskurs:

- naukowy (wypowiedzi publiczne przedstawicieli świata nauki);

- parlamentarny (wypowiedzi publiczne polityków);

- środowisk działających na rzecz równości (wypowiedzi publiczne aktywistek/ów);

- kościelny (wypowiedzi publiczne hierarchów kościelnych).

Przytoczone w niniejszym tekście przykłady wypowiedzi polskich elit symbolicznych na temat kategorii gender pochodzą z:

- dzienników Polska Times, Rzeczpospolita, Gazeta Wyborcza, Nasz Dziennik;

- najbardziej opiniotwórczych tygodników w Polsce (dane IMM z czerwca 2013) - Polityka, Wprost, Newsweek oraz Nasza Polska i Niedziela;

- portali informacyjno-publicystycznych Wirtualna Polska, Salon24, Niezalezna.pl, TVN24, Konserwatyzm.pl, Przegląd Socjalistyczny.

Taki dobór źródeł zapewnia uwzględnienie skrajnych dyskursów - zarówno liberalnych, jak i konserwatywnych środowisk. Rozważania są skoncentrowane wokół pytań: Pojęcie gender - jako co? Przez kogo jest używane? W jakim celu i kontekście? Trzeba zaznaczyć, że ze względu na ograniczoną objętość tekstu jest to jedynie próba nakreślenia specyfiki zjawisk zachodzących w dyskursie publicznym w Polsce wokół pojęcia gender.

W celu uporządkowania spostrzeżeń wykorzystano koncepcję dominujących mechanizmów dyskursu publicznego M. Czyżewskiego, S. Kowalskiego oraz A. Piotrowskiego (2010). Wyróżnili oni cztery takie mechanizmy: porozumienie, ceremonię, dramat społeczny i rytualny chaos (Czyżewski, Kowalski, Piotrowski, 2010: 7-13). 
Mechanizmy te mieszczą się w ramach dwóch głównych orientacji w dyskursie: 1) orientacji na przekładalność perspektyw oraz 2) kwestionowania zasady przekładalności perspektyw. Mechanizm porozumienia to dojście do wspólnych wniosków - produktywna ścieżka orientacji na przekładalność perspektyw. Najczęściej polega na tym, że strony zawierają rodzaj ugody roboczej, co umożliwia im podjęcie wspólnych praktycznych działań. Ceremonia również mieści się w ramach ścieżki orientacji na przekładalność perspektyw i odnosi się do sytuacji, w której obie strony przyjmują stanowisko „zawsze możemy się porozumieć”. Jest to rodzaj pozorowanego porozumienia. Dyskurs w tym przypadku jest kontrolowany poprzez wykluczanie głosów ujawniających lub podkreślających różnice stanowisk. Klasycznym przykładem są cenzurowane media państw totalitarnych i totalizujących. Dramat społeczny z kolei jest mechanizmem kwestionowania zasady przekładalności perspektyw i przebiega w czterech fazach: 1) artykulacja konfliktu, 2) eskalacja, 3) opanowywanie (twórcze opracowanie napięć; propozycje rozwiązania, inicjatywy), 4) zakończenie, które może polegać albo na jakimś rodzaju porozumienia roboczego, albo też na stabilizacji poprzedniego stanu rzeczy, ale już na innym poziomie społecznej samowiedzy. Natomiast rytualny chaos to sytuacja, w której ostentacyjnie łamie się i lekceważy orientację na przekładalność perspektyw. Brakuje w niej chęci do kompromisu, a zatem obie strony konfliktu pozostają w fazie eskalacji i bez większych efektów artykułują swoje stanowiska. Jest to zdegenerowana forma dramatu społecznego, który utknął w swojej drugiej fazie. W ten sposób powstaje stan chaosu komunikacyjnego przy pozorach stabilności sytuacji. W Polsce tak wygląda między innymi dyskurs aborcyjny. Przedłużający się stan rytualnego chaosu może w efekcie doprowadzić do anomii (Czyżewski, 2010: 49-119).

\section{Dynamika dyskursu wokół pojęcia gender}

Można wyróżnić trzy etapy rozwoju dyskursu wokół pojęcia gender. Pierwszy miał miejsce w latach 2011-2012, kiedy pojęcie gender bardzo rzadko pojawiało się $\mathrm{w}$ dyskursie publicznym $\mathrm{w}$ dosłownym sensie i w takim brzmieniu. W tym okresie pojawiały się kwestie, które dla badaczy płci społeczno-kulturowej są nieodłącznie związane z tym pojęciem, lecz rzadko pojawiało się bezpośrednio słowo gender. $\mathrm{W}$ analizowanych tekstach ze względu na temat wypowiedzi można wyodrębnić trzy dominujące subdyskursy, koncentrujące się wokół najbardziej kontrowersyjnych tematów związanych z pojęciem gender: tożsamości płciowej, związków partnerskich i homofobii. 
W roku 2013 nastąpił przełom - słowo gender po raz pierwszy zaistniało w dyskursie publicznym za sprawą przedstawicieli Kościoła katolickiego, głównie pod postacią ,ideologii gender". Ten etap można utożsamiać z fazą artykulacji konfliktu w koncepcji mechanizmu dramatu społecznego według Czyżewskiego, Kowalskiego i Piotrowskiego. Cały 2013 rok i początek 2014 to faza eskalacji konfliktu w dyskursie między środowiskami liberalno-lewicowymi a konserwatywno-katolickimi. Następnie, na przełomie lat 2014 i 2015, mieliśmy do czynienia z rozwojem tego dyskursu już z wieloznaczeniowym użyciem słowa gender, co odpowiada fazie opanowywania konfliktu i wreszcie stabilizacji poprzedniego stanu rzeczy (z lat 2011-2012), ale już na innym poziomie społecznej samowiedzy. Obecnie słowo gender nadal budzi kontrowersje, ale dyskusja wokół niego stopniowo wygasa. Każda ze stron pozostała przy własnych definicjach i reprezentacjach, aczkolwiek sama dyskusja przyczyniła się do wzrostu ogólnej świadomości społecznej dotyczącej płci społeczno-kulturowej.

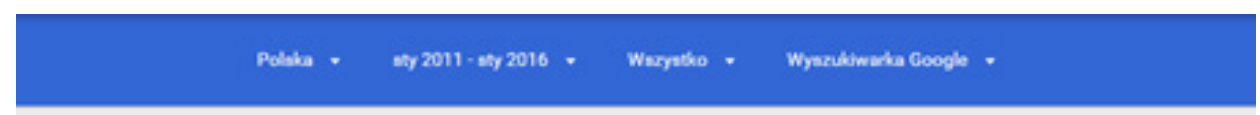

Porownaj wysubliwane hasto *

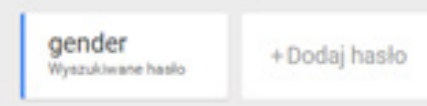

Zainteresowanie w ujęciu czasowym

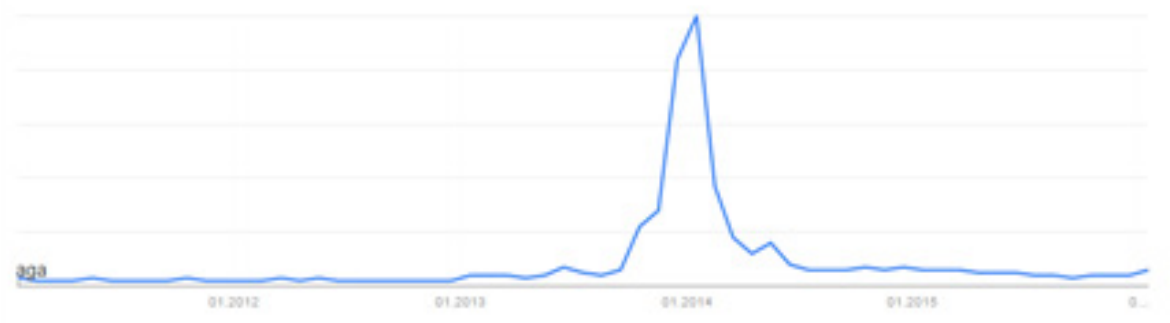

Ryc. 1. Wyszukiwania hasła „gender” w wyszukiwarce Google w latach 2011-2015

Źródło: aplikacja Google Trendy https://www.google.pl/trends/

Przemiany te są widoczne także w poziomie zainteresowania tematyką gender w Internecie w latach 2011-2015. Z wykresu trendów wyszukiwania Google (ryc. 1) wynika, że zainteresowanie tematem gender zaczęło rosnąć w połowie 
2013 roku, aby osiągnąć apogeum w styczniu 2014, następnie zaczęło stopniowo spadać, ale w połowie 2014 roku ustabilizowało się na poziomie nieco wyższym niż w latach 2011-2012. Odzwierciedla to dość dobrze przemiany w dyskursie wokół tego pojęcia, które zostaną dokładnie scharakteryzowane w dalszej części tekstu.

\section{Płeć społeczno-kulturowa w dyskursie publicznym przed artykulacją konfliktu (lata 2011-2012) - damy, smoki i rycerze (?)}

W latach 2011-2012 pojęcie gender bardzo rzadko pojawiało się w dyskursie publicznym w dosłownym sensie i w takim brzmieniu. Zebrane wypowiedzi pozwalają wyodrębnić trzy dominujące subdyskursy, koncentrujące się wokół najbardziej kontrowersyjnych tematów związanych w polskim dyskursie publicznym z pojęciem gender. Są to subdyskursy: tożsamości płciowej, związków partnerskich i homofobii.

Temat tożsamości płciowej stał się obecny w polskiej polityce głównie za sprawą jedynej jak dotąd transseksualnej posłanki w polskim parlamencie - Anny Grodzkiej. W tym obszarze dyskursu pojawiały się konstrukcje słowne wyraźnie świadczące, że płeć należy rozumieć jako konstrukt społeczny. Anna Grodzka w swoich wypowiedziach publicznych zaznaczała, że osoby transseksualne to ludzie, którzy „czują się osobami przeciwnej płci niż ta, którą nadano im w dokumentach". Jest to w pełni zgodne ze współczesnym stanem wiedzy naukowej w tym obszarze (por. Śledzińska-Simon, 2010):

D: Zamierza pani stworzyć prawo o określaniu płci. Co miałoby regulować?

Anna Grodzka: Cały proces zmiany płci i sytuację osoby transseksualnej po tej zmianie. Polskie prawo w żaden sposób nie reguluje sytuacji ludzi, którzy czują się osobami przeciwnej płci niż ta, którą nadano im w dokumentach. Funkcjonuje tylko orzeczenie Sądu Najwyższego, które na podstawie kodeksu cywilnego dopuszcza możliwość zmiany płci. Ale aby tego dokonać, trzeba w Polsce formalnie oskarżyć przed sądem swoich rodziców, co jest absurdalne. (Wrzos-Lubaś, 2011)

Mimo działań Anny Grodzkiej sposób traktowania osób transseksualnych przez prawicowych polityków nie uległ zmianie, o czym świadczą słowa Jarosława Kaczyńskiego $^{1}$ z 2014 roku:

\footnotetext{
${ }^{1} \mathrm{~W}$ tamtym czasie polski polityk, doktor nauk prawnych, twórca i prezes partii politycznych Porozumienie Centrum oraz Prawo i Sprawiedliwość, senator, poseł, były prezes Rady Ministrów, kandydat na urząd Prezydenta RP w 2010 roku. Wszystkie opisy dorobku cytowanych polityków dotyczą stanu $\mathrm{z}$ okresu, kiedy w dyskursie pojawiały się analizowane wypowiedzi.
} 
Będziemy mieli władzę, która nie będzie zajmowała się tym, żeby w Polsce nastąpiła rewolucja kulturalna i żeby tranwers... Jak to jest? (...) Żeby ci tacy różni odmienni, bardzo dziwni, mieli w Polsce lepiej i byli eksponowani. (Kośmiński, 2014)

W pierwszej z przytoczonych wypowiedzi pojawiło się neutralne wyrażenie „regulacje prawne”, w drugiej - zabarwione wartościująco słowo „eksponowanie”. Oba odnoszą się do tych samych działań - dążenia osób transseksualnych do regulacji ich sytuacji prawno-społecznej, jednak skłaniają do skrajnie różnych ocen zastanej sytuacji.

Jarosław Kaczyński już znacznie wcześniej wypowiadał się tė̇ na temat związków partnerskich:

Nie ma żadnych społecznych przesłanek, żeby tego rodzaju orientacje [w domyśle - nieheteronormatywne - M.G.] były afirmowane przez państwo (...) trzeba odróżnić wyraźnie dwa pojęcia - tolerancji i afirmacji². (PO, PiS, PSL..., 2011)

Tu również zostało użyte nacechowane negatywnie słowo „afirmacja”, sugerujące nadmierne zainteresowanie i nadawanie zbyt daleko idących przywilejów osobom homoseksualnym. Jarosław Kaczyński w swoich wypowiedziach odnosił się nie tylko do „tego rodzaju orientacji”, ale także do sytuacji kobiet. Między innymi trywializował sprawę molestowania seksualnego, mówiąc, że wyeliminuje ten problem, likwidując „spotkania integracyjne w dużych firmach” (sic!).

Jarosław Kaczyński: My z całą pewnością te wszystkie spotkania integracyjne, szczególnego rodzaju w różnych wielkich firmach, wydarzenia tego rodzaju, twardą ręką zlikwidujemy. Bo w tym wypadku trzeba po prostu to całkowicie wyeliminować. Pracownice nie mogą być poniżane, poddawane różnym zabiegom, o których nie mogę powiedzieć, bo mi wstyd, ale panie wiedzą o co chodzi ${ }^{3}$. (Kaczyński chce walczyć..., 2011)

Czynności molestowania seksualnego nazwał „zabiegami”, które panowie praktykują wobec pań, jednocześnie sugerując, że to wstydliwy problem, o którym nie powinno się mówić. Ukryty program tej wypowiedzi implikuje, że wobec problemu molestowania należy przyjąć postawę strategicznego milczenia (por. Kopciewicz, 2011: 157-159). Kobiety jawią się tu jako słabe i bierne istoty, które

\footnotetext{
${ }^{2}$ Słowa wypowiedziane na konferencji prasowej PiS po złożeniu przez SLD projektu ustawy o związkach partnerskich.

3 Wypowiedź na Kongresie Kobiet Prawicy 9 lipca 2011 Kaczyński chce walczyć o godność kobiet w Polsce, portal Wirtualna Polska, 9.07.2011, http://wiadomosci.wp.pl/title,Kaczynski-chce-walczyc-o-godnosc-kobiet-w-Polsce,wid,13582633, wiadomosc.html?ticaid=1dc67, dostęp: 15.01.2012.
} 
trzeba chronić. Przy czym obronę ich praw (a może raczej czci niewieściej) Jarosław Kaczyński uważa za rzecz pożądaną i naturalną. Przeciwnie do uznania praw osób o nieheteronormatywnej tożsamości płciowej czy homoseksualnej orientacji, które byłoby zbędną i niepożądaną „afirmacją” lub „eksponowaniem”.

Jarosław Kaczyński przyjął postawę pseudorycerską - stanął w obronie stereotypowo postrzeganych „dam”, a jednocześnie dał wyraz obawom wobec wszelkiej „inności” w zakresie tożsamości płciowych, próbując je zwalczać i odseparować od reszty społeczeństwa, jak strasznego (bo nieznanego?) smoka.

Inne przykłady wypowiedzi mieszczących się w nurcie dyskursu związków partnerskich są opinie Wandy Nowickiej ${ }^{4}$ i Mariana Piłki"

D: Jakie są wasze priorytety?

Wanda Nowicka: Nasz pakiet światopoglądowy, czyli ustawy o in vitro, o związkach partnerskich, aborcyjna. (...) Jesteśmy za usankcjonowaniem zabiegów in vitro, które są w tej chwili wykonywane. Oczywiście będziemy się domagali finansowania tych zabiegów z budżetu państwa, dla wszystkich zainteresowanych: małżeństw, par w wolnych związkach czy osób samotnych. (Olczyk, 2011)

Wanda Nowicka przedstawiała prawo do in vitro, zawierania związków partnerskich i aborcji jako naturalnie przysługujące wszystkim ludziom, ze względu na ich równość. Te same dążenia przez Mariana Piłkę z prawicy zostały jednoznacznie nazwane „promowaniem” feminizmu, aborcji i homoseksualizmu:

Marian Piłka: (...) promowanie feminizmu, aborcji, homoseksualizmu i innych dewiacji, niszczy zasoby, które są źródłem siły duchowej i moralnej... (Piłka, 2011)

W przywołanej wypowiedzi pojawiła się mowa nienawiści. Nazwanie osób homoseksualnych „dewiantami” miało zlekceważyć i poniżyć politycznych oponentów, ale Marian Piłka w „dewiantach” upatrywał też zagrożenia dla duchowej i moralnej siły. Taki sposób użycia języka jest zgodny z koncepcją Judith Butler, która pisze:

${ }^{4}$ Polska działaczka społeczna, feministka, polityczka, z wykształcenia filolog klasyczna, przewodnicząca Federacji na rzecz Kobiet i Planowania Rodziny, posłanka na Sejm i wicemarszałek Sejmu VII kadencji.

${ }^{5}$ Prawicowy polski polityk od połowy lat 70. zaangażowany w działalność opozycyjną. W czasie stanu wojennego internowany przez okres około roku. Do 2007 w Prawie i Sprawiedliwości, potem przystąpił do nowo tworzonej Prawicy Rzeczypospolitej. W 2015 bez powodzenia ubiegał się o mandat poselski z listy PiS. 
Raniące wezwanie może wydawać się przygniatające lub paraliżujące adresata, lecz może również wywołać nieoczekiwaną i otwierającą nowe możliwości odpowiedź. (...) Jeśli nazwanie jest interpelacją [ustanowienie podmiotu w języku - M.G.], to zniewaga wystawia się na ryzyko, że powoła do życia w mowie podmiot, który użyje języka przeciw niej. (Butler, 2010: 10)

Tego typu odpowiedzią, czy też użyciem języka przeciwko zniewadze, może być używanie słowa "homofob” wobec konserwatywnych polityków. Fobia to zaburzenie związane ze stanem psychicznym dotkniętej tą przypadłością osoby. Zatem pejoratywne określenie „dewiant” spotyka się z równie negatywnym w znaczeniu słowem „homofob”, które oznacza obecnie już nie tylko osobę odczuwającą lęk, wstręt, niechęć przed zetknięciem się z osobami o orientacji homoseksualnej, ale szerzej - nietolerancyjnego człowieka o ciasnych horyzontach myślowych, z licznymi kompleksami, wykazującego nieuzasadnioną nienawiść wobec osób o nieheteronormatywnej tożsamości rodzajowej. W opisywanej sytuacji podmiot ustanowiony w języku poprzez nazwanie „dewiantem”, używa języka jako oręża w walce o swoją godność i prawa. Strach przed innością wyrażający się w słowie „dewiant” powoduje, że prawomocne i uzasadnione staje się użycie przeciw niemu równie negatywnego wezwania - „homofob”.

Inne niesprzyjające postulatowi związków partnerskich wypowiedzi pochodzą z ust Jarosława Gowina ${ }^{6}$ :

Będę głosował przeciw. Nie wyobrażam sobie, że w takiej sprawie będzie dyscyplina. To jest typowa sprawa sumienia. Przypuszczam, że wyraźna większość PO ma w tej sprawie takie zdanie jak ja. Aczkolwiek nie mogę wykluczyć, że pod wpływem perswazji premiera część osób zmieni opinię, tak jak było w przypadku parytetów. (Grochal, 2011)

Z góry zakładał on, że większość polityków z jego partii ma równie konserwatywne poglądy jak on. Odwoływał się przy tym do kategorii sumienia, jednocześnie w bardzo zawoalowany sposób wskazując, że głosowanie „za” związkami partnerskimi jest złe, niezgodne z sumieniem „normalnego” człowieka. Sugerował też, że ci, którzy zagłosują „za”, zrobią to nie z własnej woli, a zmuszeni przez ówczesnego premiera rządu.

Poniżej przytoczono kolejne dwa skrajnie różne cytaty dotyczące ponownie kwestii związków partnerskich:

${ }^{6}$ Polski publicysta, senator VI kadencji, poseł na Sejm VI i VII kadencji, od 2011 do 2013 minister sprawiedliwości. Od 2015 wiceprezes Rady Ministrów oraz minister nauki i szkolnictwa wyższego. 
Robert Biedroń: W Polsce żyje zgodnie ze statystykami kilkaset tysięcy takich par, które oczekują uregulowania tych kwestii od państwa. Nie tylko jednopłciowych, ale także różnopłciowych. Powinniśmy się zastanowić, jak pomóc tym obywatelom. To nic nie kosztuje budżetu państwa, to jest kwestia, która dotyczy praw człowieka, swobód obywatelskich. (Relacja $\mathrm{z}$ audycji..., 2011)

Jarosław Gowin: Ustawa o związkach partnerskich tylnymi drzwiami wprowadzałaby małżeństwa homoseksualne. Dla mnie małżeństwo z definicji jest związkiem kobiety i mężczyzny. Tak zresztą definiuje je nasza konstytucja. (...) W całym tym projekcie nie chodzi naprawdę o dobro konkretnych ludzi, tylko o przeprowadzenie rewolucji obyczajowej, odejście od tradycyjnej moralności. (Grochal, 2011)

To, co dla Roberta Biedronia ${ }^{7}$ jest kwestią praw obywatelskich, dla Jarosława Gowina jest próbą przeprowadzenia rewolucji obyczajowej. W konserwatywnym ujęciu tylko związek kobiety i mężczyzny jest związkiem moralnym.

Robert Biedroń: To jest sfera niezbędna do codziennego życia. Sam jestem w takim związku wieloletnim z moim partnerem i, od dziewięciu lat tworząc ten związek, nie mogę się z nim rozliczać z podatków. Dlaczego, kiedy prowadzimy razem gospodarstwo domowe, kiedy razem zarobione pieniądze wydajemy, kiedy chcemy decydować o naszym życiu i zdrowiu, kiedy chcemy po sobie dziedziczyć, nie możemy tego w państwie demokratycznym zrobić? Jesteśmy dwoma dorosłymi mężczyznami, którzy razem prowadzą po prostu gospodarstwo domowe. W większości krajów Unii Europejskiej ten problem został rozwiązany. Dlaczego w Polsce nie mielibyśmy tego rozwiązać? (Relacja z audycji..., 2011)

Jarosław Gowin: Ale de facto poza prawem do adopcji dzieci są wszystkie pozostałe prawa i przywileje małżeńskie - na przykład przywilej wspólnego rozliczania podatkowego. A wynika on z tego, że małżeństwa biorą na siebie ciężar wychowywania dzieci. A w przypadku homoseksualistów to jest wykluczone.

D: To małżeństwom bezdzietnym chce pan ten przywilej zabrać?

Jarosław Gowin: To typowa demagogia poprawności politycznej. Małżeństwo co do swej istoty nakierowane jest na posiadanie dzieci, choć czasami małżonkowie z tego rezygnują lub - częściej - nie mają takiej możliwości. Związek homoseksualny z istoty wyklucza posiadanie dziecka biologicznego. (Grochal, 2011)

To, co dla Roberta Biedronia, żyjącego w długoletnim związku ze swoim partnerem, jest podstawowym prawem, z którego może skorzystać obywatel w demokratycznym kraju (wspólne rozliczanie się z podatków), dla Gowina w przypadku par homoseksualnych jest niedopuszczalne. Przy czym zastosował on bardzo

7 Działacz na rzecz osób LGBT, publicysta i polityk, poseł na Sejm VII kadencji (2011-2014); w latach 2014-2018 prezydent Słupska, deputowany do Parlamentu Europejskiego IX kadencji (od 2019). 
niejednoznaczne wytłumaczenie dla swych poglądów, dotyczące (nie)możności posiadania dzieci:

Jarosław Gowin: Nie widzę tu żadnej dyskryminacji. Z dyskryminacją mielibyśmy do czynienia tylko w sytuacji, gdyby prawo przyznawało inne przywileje różnym grupom małżeństw. A ponieważ małżeństwo i związek partnerski mają inny charakter, to inne też w odniesieniu do nich powinny obowiązywać regulacje. (...) Powtórzę: małżeństwo jest ważną instytucją społeczną, bo dźwiga na sobie fundamentalny z punktu widzenia interesu społecznego obowiązek wychowania dzieci. Ponieważ związki homoseksualne takiej misji nie pełnią, nie powinny oczekiwać zrównania praw. (Grochal, 2011)

Zasugerował w ten sposób, że obawia się jedynie niżu demograficznego, związanego z dramatycznym spadkiem urodzeń, co w gruncie rzeczy dzieje się zupełnie niezależnie od sytuacji prawnej związków jednopłciowych w Polsce. Wśród konserwatywnych polityków częste jest też odwoływanie się do kategorii „Polacy”, „polskie społeczeństwo” - w domyśle większość. I tak na przykład Robert Węgrzyn ${ }^{8}$ twierdził, że większość polskiego społeczeństwa uważa tradycyjną rodzinę za najwyższą wartość, a siebie przedstawiał jako obrońcę tejże wartości. Nie miał na poparcie tej tezy żadnych argumentów - nie przytoczył wyników badań, analiz ani żadnych innych faktów, które mogłyby świadczyć, że ma rację.

Robert Węgrzyn: Polscy politycy i - co kluczowe - polskie społeczeństwo, które ich wybiera, uważa rodzinę w tradycyjnym znaczeniu za wartość najwyższą. Mam nadzieję, że chcąc bronić jej praw, nikt nie będzie już musiał płacić tak wysokiej politycznej ceny jak ja. Ale, żeby nie było wątpliwości: wcale nie uważam się za męczennika, jestem też przekonany, że ci, którzy chcieli mnie wyautować z polityki z konserwatywne poglądy obyczajowe jesienią przekonają się, jak gruby błąd popełnili... (Meller, 2011)

Wydaje się to kuriozalne, zważywszy na słowa, które ostatecznie przyczyniły się do politycznej klęski posła Węgrzyna. W świetle tej niepoprawnej politycznie, ale i kontrowersyjnej pod względem obyczajowym wypowiedzi ${ }^{9}$ jawił się on raczej jako mężczyzna o wybujałej erotycznej fantazji i niezaspokojonych potrzebach (w języku potocznym „erotoman-gawędziarz”) niż obrońca tradycyjnych wartości. Z perspektywy czasu przyjął jednak postawę konserwatywnego orędownika tradycyjnych wartości i opartej na nich moralności. Jego działania defensywne (obrona

\footnotetext{
${ }^{8}$ Polski polityk, przedsiębiorca i samorządowiec, poseł na Sejm VI kadencji.

9 Powiedział wówczas: „Z gejami to dajmy sobie spokój, ale z lesbijkami, to chętnie bym popatrzył".
} 
swojej pozycji) ubrane zostały w barwy szlachetnej (niemal powstańczej) walki dla dobra społeczeństwa, która ostatecznie zakończyła się klęską i męczeńską śmiercią „obrońcy”.

Robert Węgrzyn: Wierzę, że konserwatywne skrzydło PO wraz z PiS-em okaże się na tyle mocne, że do legalizacji związków homoseksualnych nie dojdzie, gdyż byłoby to otwarcie drogi do kolejnych żądań, w tym adopcji dzieci. (Meller, 2011)

Ustawa o związkach partnerskich jawiła się w jego wypowiedziach jako zaledwie wierzchołek góry żądań par homoseksualnych. Była to wyraźna próba manipulacji - poseł Węgrzyn przedstawiał postulaty środowisk LGBTQ jako zagrożenie, które, lepiej żeby się nigdy nie pojawiło, bo pociągnie ze sobą dalsze konsekwencje. Według posła Węgrzyna pary homoseksualne najpierw zechcą formalnych związków, a potem „sięgną” po (nasze wspólne) dzieci, w myśl zasady „dasz im palec, a wezmą całą rękę”. Jest to wyolbrzymienie i manipulacja poprzez celowe przedstawienie wszelkich postulatów środowisk LGBTQ jako zagrażających większości.

Kolejny wątek przewodni to właśnie homofobia. To słowo padające z ust liberalnych i lewicowych polityków jest obelgą. Czasami przypisuje się zachowania homofobiczne ukrytym gejom. Za takiego był też w niektórych kręgach uważany Jarosław Kaczyński ze względu na swoje niepochlebne opinie i wrogie nastawienie wobec osób LGBTQ. Świadczy o tym poniższa wypowiedź:

Robert Biedroń: Przecież Kaczyński jest homofobem. Palikot ma prawo pytać, czy jest gejem, skoro Kaczyński atakuje innych gejów. W takich sytuacjach nie ma dylematu moralnego, bo mamy do czynienia z nietolerancją. Jestem za całkowitym outingiem takich osób! Hipokryzje należy obnażać, szczególnie osób publicznych, w tym polityków. (Prekiel, 2011)

Polityk prawicy zapytany o homofobiczne zachowania lub wypowiedzi z góry traktuje tego typu pytania jako atak lub jako podyktowane polityczną poprawnością (cokolwiek przez to rozumie) i nadaje im status insynuacji skierowanych przeciw niemu.

D: Jest pan homofobem?

Jarosław Gowin: Za pani pytaniem kryje się dyktat politycznej poprawności. Nie obchodzi mnie orientacja seksualna innych ludzi, ale nie godzę się na to, by środowiska homoseksualne dokonywały pieriekowki dusz. Żadna polityczna poprawność nie zmusi mnie do tego, żebym mówił, że trawa jest biała, a nie zielona. Ani do tego, bym kwestionował tezę, że małżeństwo to związek kobiety i mężczyzny. (Grochal, 2011) 
Tymczasem homofobia, zdaniem Roberta Biedronia, jest już dawno passé:

Robert Biedroń: Dzisiaj [Eliza Michalik ${ }^{10}$ homofobię uważa za obciach, bo poczytała, poznała gejów i lesbijki, zmieniła się. Przecież o to nam wszystkim chodzi - żeby zmieniać homofobiczne postawy. (Prekiel, 2011)

Nie wszyscy jednak podzielali wówczas jego zdanie. Robert Węgrzyn w swych „fobiach” posunął się nawet do upatrywania zagrożenia w bliżej niezdefiniowanym „homoseksualnym lobby”. Używał przy tym języka wojny („wróg”, „postulaty”), w której owo lobby miało być stroną wspieraną przez niektóre media, a orężem były „raniące nazwania” (homofobia) i mocne argumenty (sprzeciw wobec adopcji dzieci przez pary homoseksualne):

Robert Węgrzyn: Nie mieliby oni jednak możliwości nadania niefortunnemu, ale w gruncie rzeczy błahemu żartowi tak monstrualnych rozmiarów, gdyby nie to, że lobby homoseksualne traktuje dziś jako swojego wroga i piętnuje każdego, kto ośmiela się sprzeciwiać jego postulatom. A ma takie możliwości, gdyż owemu lobby sprzyjają potężne media, w tym Gazeta Wyborcza, na której łamach homofobią nazywany jest nawet sprzeciw wobec powierzania na wychowanie dzieci parom lesbijsko-gejowskim. (Meller, 2011)

W tej wypowiedzi także pojawił się argument z gatunku: „bo większość tak uważa", co przez Artura Schopenhauera sklasyfikowane zostało jako jedna z klasycznych technik erystycznych zwana argumentum ad verecundiam (Schopen-hauer, 2010: 47-52). Temu, co sądzi większość, nadawany jest wyższy status. Przy czym zdanie większości wyznacza granice „normalności”. To, co znajduje się poza tymi granicami, po stronie mniejszości, staje się automatycznie „nienormalne”.

D: Jaki jest stosunek większości posłów PO wobec postulatów homoseksualnych aktywistów?

Robert Węgrzyn: Większość z całą pewnością ma stosunek negatywny lub co najwyżej obojętny. Właśnie dlatego wypowiedzi większości polityków PO w tej sprawie są mętne i niejednoznaczne, bo nie chcąc się narażać homoseksualistom, w gruncie rzeczy nie popierają ich żądań. Jedyną siłą w polskiej polityce, która chce dziś podkopać instytucję małżeństwa jako fundamentu społecznego ładu, jest SLD. (Meller, 2011)

Natomiast lewica popierająca postulaty poszanowania praw osób homoseksualnych była oskarżana o podkopywanie fundamentów społecznego ładu. Takie ujęcie sprawy również wydaje się zręczną manipulacją.

${ }^{10}$ Polska dziennikarka prasowa i telewizyjna, prowadząca audycję Czekając na środę, czyli godzina niepoprawności politycznej. 


\section{Gender-boom (rok 2013)}

Rok 2013 był przełomowym ze względu na zainteresowanie pojęciem gender, a jednocześnie był rokiem, w którym $\mathrm{w}$ dyskursie publicznym to słowo zaczęło się pojawiać wyjątkowo często. Zauważalna jest obfitość tekstów i wypowiedzi dotyczących tej tematyki w omawianym okresie. Przykładowe tytuły artykułów w najpopularniejszych tygodnikach, które ukazały się w tym czasie, a dotyczą kwestii związanych z płcią społeczno-kulturową, to: Trzecia płeć; Co się stało księdzu Oko; Pytania o homozwiazki; Zaprosić pogan na dziedziniec; Czy mózg ma płeć?; Życie seksualne pierwotniaków; Kobiety wychodza z jaskini; Szycie życia na miarę; Równaj krok!; Pyskówka nad przemocą; Gej też twardziel; Kobiety! Witajcie w nierealu!; Wszyscy jesteśmy trochę homo; Pierwsza rolniczka RP; Geje służa państwu; W uchylonych drzwiach szafy; Płeć wysokiego ryzyka; Siła kobiet; Albo miłość, albo seks; Uwięzieni w obcym ciele; Homo poza norma; Homorewolucja; Była przystojnym facetem; Zakazane związi.

Na podstawie analizy treści tekstów z tego okresu powstała poniższa mapa mentalna pojęcia gender $\mathrm{w}$ dyskursie publicznym.

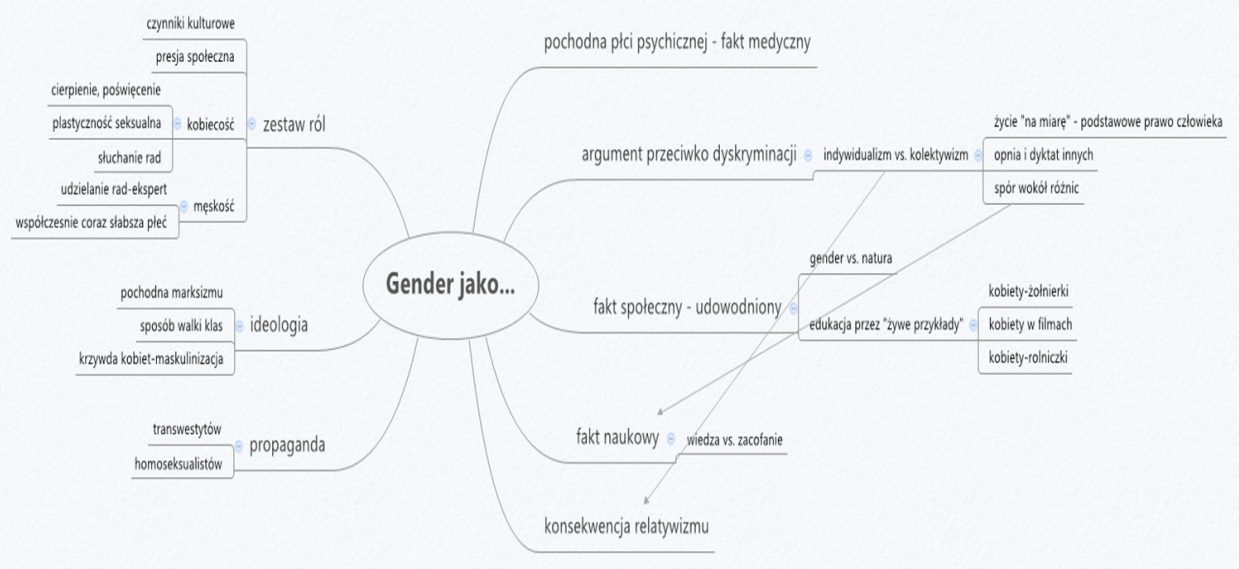

Ryc. 2. Mapa mentalna pojęcia gender

Źródło: opracowanie własne

W świetle analizowanych wypowiedzi i artykułów gender pojawia się w ośmiu podstawowych znaczeniach:

- jako zestaw ról - w tym ujęciu płeć społeczno-kulturowa jest postrzegana jako oddziaływanie czynników kulturowych na jednostkę, co jest odczuwalne w postaci presji społecznej na odgrywanie ról społecznych przypisywa- 
nych jednostce na podstawie płci biologicznej; przy czym kobiecość w tym dyskursie łączy się z cierpieniem, poświęceniem, seksualną plastycznością, słuchaniem rad, natomiast męskość - z udzielaniem rad (eksperckość) oraz ubolewaniem nad współczesnym osłabieniem tej płci;

- jako ideologia - jest pochodną marksizmu, nowym sposobem walki klas i krzywdzeniem kobiet poprzez ich maskulinizację;

- jako propaganda - w dyskursie wiąże się z „afirmacją” transwestytów i homoseksualistów;

- jako pochodna płci psychicznej - rozumienie zakorzenione w nauce - fakt medyczny;

- jako argument przeciwko dyskryminacji - płeć społeczno-kulturowa jest postrzegana jako wyraz walki pomiędzy tym, co indywidualne, a tym, co kolektywne; w tym rozumieniu uznaje się, że każdy ma prawo kształtować swoje życie tak jak chce, niezależnie od płci, koncepcje gender traktowane są jako droga do wyzwolenia od dyktatu opinii innych ludzi; w tym dyskursie podkreśla się też istnienie wielu naukowych koncepcji dotyczących różnic między kobietami a mężczyznami, które pozostają ze sobą w ciągłym sporze;

- jako fakt społeczny - istnieje mnóstwo dowodów na znaczenie wzorców kulturowych w kształtowaniu ról społecznych; to, co biologiczne, jest związane z naturą, wszystko inne to "nadbudowa” kulturowa; aby zmienić ograniczające role, trzeba stosować edukację przez „żywe przykłady” na przykład kobiet pełniących nietradycyjne funkcje - żołnierek, rolniczek, pierwszoplanowych aktorek i reżyserek itp.;

- jako fakt naukowy - w tym dyskursie przeciwstawia się wiedzę naukową na temat płci społeczno-kulturowej zacofaniu; często nawiązuje się do faktów i mitów na temat różnic między kobietami a mężczyznami;

- jako konsekwencja relatywizmu - relatywizm jako „znak naszych czasów”, zjawisko negatywne, porzucenie tradycyjnych wartości; w dyskursie jest związany z porzuceniem kolektywizmu na rzecz indywidualizmu.

Dyskursy płci społeczno-kulturowej ze względu na typ argumentacji i uzasadniania racji można skategoryzować jako: medyczny, naukowy, społeczny i kościelny.

W tekstach mieszczących się w dyskursie naukowym pojawiały się najczęściej wyniki badań naukowych oraz nazwiska badaczy i badaczek - autorytetów (Alfred Kinsey, Fritz Klein, Lisa Diamond). Były one używane jako argument potwierdzający prawdziwość podawanych informacji na temat płci społeczno-kulturowej. $\mathrm{Na}$ poparcie tez często były podawane również tak zwane „przykłady z życia”. 
Współcześni badacze twierdzą, że orientację seksualną najlepiej wyobrażać sobie w formie skali rozciągającej się między skrajnymi biegunami homo- i heteroseksualizmu. (Bratkowska, 2013)

W dyskursie publicznym toczył się spór wokół tego, co jest „prawem naturalnym”, a co jedynie konstruktem społecznym. Widoczna była krytyka logiki prawicowych polityków i przeciwstawianie jej poglądów naukowych.

Seksuolodzy już od jakiegoś czasu przyznają, że nie ma dwóch płci. Jest ich - według najczęściej ostatnio przytaczanej koncepcji - aż dziesięć. (Bratkowska, 2013)

Często stosowany był zabieg uwiarygadniający w postaci prowadzenia wywiadu z ekspertem/ekspertką.

Mężczyźni mówią mniej, ale, co potwierdzają badania, bardziej wprost. Kobiety mówią więcej, ale liczą na to, że druga osoba zgadnie, do czego zmierzają i co chcą wyrazić. (Sowa, 2013)

Powyższy cytat pochodzi z wywiadu z ekspertką i jest przykładem rozumienia płci społeczno-kulturowej jako zestawu ról. Ten dyskurs charakteryzuje się dążeniem do obiektywizmu, racjonalnością i operowaniem jedynie faktami, a nie ocenami.

Podobnie oddziałuje dyskurs medyczny. Tu też poszukuje się autorytetów, które mają za zadanie uwiarygodnić stawiane tezy. Następnie pokazywane są przykłady ludzi, którzy doświadczyli omawianych zjawisk.

(...) to transpozycja, która powstaje już w okresie życia płodowego, ma charakter wrodzony, więc trwały i niezmienny, ale nie jest to dziedziczne. (Smolińska, 2013)

Uzasadnione faktami medycznymi regulacje prawne dotyczące osób transseksualnych, stosowane w innych krajach, były w tych tekstach argumentem za wprowadzeniem podobnych zmian w Polsce. Często było obecne przeciwstawienie wysokiego poziomu wiedzy krajów zachodnich polskiemu zacofaniu.

Chodzi o ułatwienie życia dzieciom, które rodzą się z narządami płciowymi obu płci na raz (...) płeć subiektywnie odczuwana i przeżywana należy do podstawowych praw człowieka. (Trzecia płeć, 2013)

Taka medyczna argumentacja i wyniki analiz eksperymentów medycznych są używane w celu uzasadnienia postulatów osób transpłciowych, ale także w celu uzasadnienia różnic między kobietami a mężczyznami: 
(...) uszkodzenia lub dysfunkcje podobnych części mózgu mają odmienne skutki u pań i panów. (Cieśla, 2013)

W ten sposób fakty medyczne mają kształtować życie społeczne. Autorytety medyczne bezsprzecznie należą do elit symbolicznych, uzurpujących sobie prawo do sprawowania władzy poprzez narzucanie dominujących znaczeń w dyskursie.

Również autorytet znanych sportowców był używany w celu uprawomocnienia pewnych tez związanych z płcią społeczno-kulturową i orientacją seksualną. Niezależnie od tego, czy miały one wydźwięk pozytywny:

(...) geje w piłce są OK, powinni się ujawnić, dostaną od środowiska pełne wsparcie. (Jarkowiec, 2013)

czy negatywny, czego przykładem mogą być niepochlebne opinie Jana Tomaszewskiego ${ }^{11}$ o gejach $\mathrm{w}$ piłce nożnej, jak i reakcja środowisk sportowych na te słowa. Zwyczaje w piłce nożnej z krajów zachodnich były używane w tym kontekście jako argument antyhomofobiczny. W tytule cytowanego powyżej artykułu pojawia się postać "geja-twardziela” - tu także termin gender jest rozumiany jako zestaw ról, które mogą i powinny ulegać zmianom wraz z postępem cywilizacyjnym. W taki sposób w swoich felietonach pisała prof. Magdalena Środa, kojarzona również z aktywnością organizacjach feministycznych:

W pismach zwanych kobiecymi mężczyźni występują w roli „twardych” doradców, na przykład finansowych oraz ginekologicznych. Kobiety w rolach „miękkich” - jako psycholożki, dietetyczki... (Środa, 2013)

W tekstach prasowych często przywoływane były reprezentacje kulturowych kanonów kobiecości (także cielesne), co również jest wyrazem rozumienia płci społeczno-kulturowej jako zestawu ról. Jeśli są one stereotypowe, spotykają się z krytyką ze strony środowisk liberalnych i pochwałą ze strony środowisk prawicowych i odwrotnie.

Mężczyźni pokazywani w tym roku na festiwalowym ekranie to bez dwóch zdań słaba płeć... (Pietrasik, 2013)

${ }^{11}$ Polski piłkarz, trener, publicysta sportowy; wielokrotny reprezentant Polski w piłce nożnej, medalista olimpijski; poseł na Sejm VII kadencji. 
W dyskursie prasowym ukazywane są także przemiany w pełnieniu ról społecznych przez kobiety i mężczyzn, co dowodzi ich społeczno-kulturowego charakteru.

W tym okresie szczególnie słyszalny stał się głos przedstawicieli Kościoła katolickiego w dyskusji o gender, zwłaszcza za sprawą głównego propagatora tezy o szkodliwości tak zwanej „ideologii gender” - ks. Dariusza Oko. Publiczne wypowiedzi hierarchów kościelnych z tego okresu były bardzo specyficzne. Dominował w nich dyskurs wojny, który niejednokrotnie ocierał się o mowę nienawiści, a z całą pewnością zachęcał do stosowania mowy nienawiści wobec osób o nieheteronormatywnych tożsamościach i poglądach feministycznych. Wyrażenia będące w tym dyskursie synonimami gender to:

- „śmiercionośna wizja antropologiczna negująca nasz status stworzenia, a zwłaszcza naszą tożsamość" (Gracz, 2013);

- "propaganda progenderowa” (Gracz, 2013),

- „droga nieszczęścia” (Gracz, 2013) i „objaw ludzkiej pychy” (Bruchwald, 2013);

- „Zwolennicy ideologii gender atakują” (Zwolennicy ideologii..., 2013) - są wrogami Boga, wrogami chrześcijan, wrogami demokracji;

- „genderyzm to zagrożenie” (Oko, 2013), „zniszczenie rodziny - zniszczenie społeczeństwa" (Wesołowski, 2013);

- „narzędzie bezwzględnej walki o swoje interesy” (Cichobłazińska, 2013);

- „gender groźniejsze od marksizmu” (Jędrzejczyk, 2013);

- skrajność w zwalczaniu dyskryminacji.

Powodowały one wzrost negatywnych odczuć w stosunku do ludzi o poglądach odbiegających od doktryny Kościoła katolickiego, stwarzając przy tym wrażenie pozostawania Kościoła w stanie wojny z bliżej nieokreślonym genderowym wrogiem. Pojawiały się porównania tak zwanej „ideologii gender” do bolszewizmu, komunizmu, marksizmu, faszyzmu. Terenem tej walki stały się media oraz szkoła, a narzędziem - socjotechniki.

Jednocześnie pojawił się nurt wyrażający sprzeciw wobec takiego ujęcia płci społeczno-kulturowej. Charakterystyczne dla niego były personifikacje gender jako zwierzęcia lub potwora, także w wersji rysunkowej, pod postacią rozprzestrzeniających się w sieci memów, ośmieszające pozbawione podstaw naukowych podejście Kościoła do tych kwestii.

Kontrowersyjne cytaty z Pisma Świętego były stosowane jako argument służący krytyce kościelnej nieakceptacji homoseksualizmu:

W Piśmie znajdziemy jednak - jako zgodne z normą - zachowania takie, jak: poligamia, uznanie dla niewolnictwa, bezwzględne podporządkowanie kobiet mężczyznom... (Środa, 2013) 
Z otwartą krytyką spotkało się także ukute przez hierarchów kościelnych pojęcie „ideologia gender”:

Gender to świetny wynalazek na trudne czasy dla Kościoła. Słowo zagraniczne, nie każdy wie, co znaczy, więc wszystko właściwe można pod nie podciągnąć. (Tym, 2013)

Przedstawiano je jako temat zastępczy, mający za zadanie odwrócić uwagę od rzeczywistych problemów Kościoła, związanych chociażby z pedofilią wśród księży. Krytyki kościelnego dyskursu „ideologii gender” dokonywano także poprzez kompromitowanie jego głównego propagatora z 2013 roku - księdza Oko.

[ks. Oko] używa coraz to bardzie zdumiewających - jak na profesora Wydziału Filozofii Papieskiego Uniwersytetu w Krakowie - argumentów. Sugeruje na przykład, że wśród popierających ideologię gender są „wszyscy wrogowie Boga i religii, zwłaszcza religii biblijnych” (...), a wśród nich „oczywiście masoni, ale także grupa najbogatszych miliarderów amerykańskich, którzy doszli do przekonania, że na Ziemi jest za dużo ludzi”... (Burnetko, 2013)

Konteksty towarzyszące tematowi gender we wszystkich wyżej wymienionych dyskursach to:

- rodzina i jej przemiany,

- przemoc,

- wojna,

- homoseksualizm,

- transseksualizm,

- wiara.

Zatem to, co w latach 2011-2012 było samodzielnym tematem $\mathrm{w}$ dyskursie publicznym - tożsamość płciowa, związki partnerskie i homofobia - w 2013 roku stało się zaledwie kontekstem pojawiającym się w tle dyskusji o gender, które to pojęcie wyraźnie wysuwa się na pierwszy plan.

Treści dominujące w dyskursie publicznym w 2013 roku można podzielić na dwa typy:

- neutralne - zawierające definicje terminów związanych z gender, służące wyjaśnianiu rzeczywistości społecznej, albo informacje o gender studies;

- zabarwione emocjonalnie - o wydźwięku negatywnym, obecne głównie w dyskursie kościelnym; w tych tekstach pojęcie gender jest przedstawiane jako szkodliwa, zagrażająca ludzkości ideologia lub zawierające ostrą krytykę podejścia duchownych.

Ów chaos informacyjny mógł powodować poczucie zagubienia wśród czytelniczek i czytelników prasy. Ponadto dyskurs wojny nie sprzyjał nawiązywaniu dia- 
logu między wrogimi sobie środowiskami. Ich przedstawiciele prezentowali postawę zamknięcia na wszelkie argumenty. Stosowali jedynie techniki ośmieszania lub straszenia zwolenników przeciwnych poglądów. Obiektywnym, naukowym argumentom były przeciwstawiane argumenty nacechowane skrajnie negatywnymi emocjami.

W ten sposób różnice między zwalczającymi się obozami stawały się coraz większe, a szanse na porozumienie i zażegnanie konfliktu - nikłe. Współistnienie $\mathrm{w}$ przestrzeni publicznej tych dwóch zantagonizowanych środowisk niosło negatywne skutki społeczne. Zwykli odbiorcy tych komunikatów mogli czuć się niekomfortowo. Opowiadając się po którejkolwiek ze stron, byli narażeni na ataki drugiej strony konfliktu. Konsekwencje ponosiła także szkoła jako instytucja, która jest bezbronna wobec prób zideologizowania jej przez różne środowiska. $\mathrm{Z}$ jednej strony w szkole powinny być prezentowane jedynie naukowe fakty, $\mathrm{z}$ drugiej - nie są one nigdy wolne od ocen przez indywidualne preferencje światopoglądowe nauczycieli. Ponadto w szkole prowadzi się lekcje religii, z gruntu dalekie od prezentowania naukowych faktów. Nauczyciele przekazują swoim uczniom różne idee. Jeśli na różnych lekcjach są prezentowane skrajnie różne poglądy, uczniowie mogą czuć się zagubieni. Dyskursy obecne w przestrzeni publicznej, jak w zwierciadle, odbijały się w codzienności szkolnej w postaci z jednej strony - listów środowisk katolickich przestrzegających przed „genderem” kierowanych do dyrektorów szkół, z drugiej - w projektach środowisk prorównościowych, dotyczących na przykład rzetelnej edukacji seksualnej, co w pewnym momencie również zaczęło przypominać pole walki. Ma to duże znaczenie w procesie społecznego uczenia się ról przez dzieci i młodzież, gdyż powoduje chaos, owocując poczuciem zagubienia u młodych ludzi. Poza tym istnieje ryzyko, że przyswoją oni tradycyjne wzorce ról jako jedyne „prawidłowe”, w dorosłym życiu okupując to niską jakością życia, poczuciem niespełnienia i ograniczenia możliwości rozwoju.

\section{Płeć społeczno-kulturowa w dyskursie publicznym w fazie opanowywania konfliktu (lata 2014-2015)}

W latach 2014-2015 wątpliwości i oceny związane z kwestiami gender w prasie były nadal obecne w podobnej formie - walki dwóch obozów. Świadczą o tym poniższe przykłady:

W Polsce zostało wykreowane nowe pojęcie: ideologia gender. W praktyce nic takiego nie istnieje - za tym pojęciem nic nie stoi, to puste słowa. Ksiądz Dariusz Oko, który od miesięcy objeżdża Polskę z wykładami o ,ideologii gender”, pytany u Moniki Olejnik nie potra- 
fił wskazać żadnej osoby ani instytucji, która stałaby za tą straszną, antyrodzinną krucjatą. Ta ideologia, „gorsza od nazizmu i marksizmu”, nie ma żadnego lidera ani wykonawców. Ja też nie znam ani jednej osoby, ani instytucji w Polsce, która jest przeciwko rodzinie, chce seksualizować dzieci, uczyć je masturbacji, zmieniać im płeć itp. Nie ma takich rzeczy w żadnym programie partii, instytucji czy szkoły, podobnie jak nie ma żadnej „ideologii gender”. (Kopiński, 2014)

Gedner wychodzi z niewłaściwego pojmowania wolności. W radykalnej wersji nie uznaje Boga, jego przykazań, prawa natury, sprzeciwia się wszelkim trwałym związkom międzyludzkim. Dla genderystów absurdem jest chrześcijańska nierozerwalność małżeństwa. Wszystko jest ukierunkowane na to, żeby robić, co się chce. To, co w tej ideologii jest pożyteczne, ginie w mroku otoczek, które sprowadzają się do zmiany świata i postawienia go na głowie. Gender chce dokonać rewolucji obyczajowej. Ale to się mu nie uda. Jak każda mroczna ideologia, gender nie ma przyszłości. (Nizinkiewicz, 2014)

- Obwinianie przez Kościół studiów czy dyscypliny naukowej o nieobyczajność jest nieporozumieniem. Gender nie jest jedynym winowajcą zmian społecznych - mówi „Newsweekowi” politolog prof. Agnieszka Rothert z Instytutu Nauk Politycznych Uniwersytetu Warszawskiego, ekspertka od ruchów feministycznych i gender studies.

D: Czym w zasadzie są gender studies?

prof. Agnieszka Rothert: W tego typu emocjonalnych dyskusjach, a ta związana jest jeszcze ze stanowiskiem Kościoła, są one określane ideologią, co absolutnie nie jest prawdą. Są to studia nad płcią, tyle że rozumianą w ujęciu kulturowym, a nie biologicznym. (Rogojsz, 2014)

W tym okresie dyskurs publiczny w Polsce nadal był zdominowany przez dyskurs Kościoła katolickiego. Rozumienie zjawisk związanych z płcią społeczno-kulturową rządzącej politycznej prawicy było w pełni zgodne z postanowieniami synodu biskupów:

Jeszcze przed sobotnim głosowaniem austriacki kardynał Christoph Schönborn stwierdził, że „niektórzy ludzie będą zawiedzeni”, ponieważ w dokumencie bardzo mało miejsca poświęcono homoseksualistom. Powtórzono w nim stwierdzenia zawarte w ubiegłorocznej relacji posynodalnej, zgodnie z którymi nie ma podstaw do tworzenia analogii między związkami homoseksualnymi a małżeństwem i rodziną. W dokumencie jednocześnie zapewniono, że każda osoba, niezależnie od orientacji seksualnej, musi być „szanowana”. Jak przyznał Schönborn, kwestia osób homoseksualnych jest „zbyt delikatna” dla biskupów $\mathrm{z}$ wielu stron świata. (Nałęcz, 2015)

Aktywiści lewicowi próbowali prostować i wyjaśniać nieścisłości w wypowiedziach hierarchów kościelnych i podążających za nimi polityków, jednak woli porozumienia i dialogu między tymi skrajnymi opcjami nadal nie było: 
Mi się wydaje, że jeżeli ktoś nie wie, czym jest gender, to chyba tylko z jakiejś niechęci, żeby sięgnąć do źródeł. Płeć społeczno-kulturowa jest obszarem, którym nauka społeczna zajmuje się od lat 70. Tu bada się, jak każda z płci reaguje, zachowuje się w danych sytuacjach. A kobiety - w związku z przypisanymi rolami - właśnie tymi społeczno-kulturowymi, są dyskryminowane - chociażby na rynku pracy. O to tutaj chodzi. Najłatwiej jest oczywiście ośmieszyć jakąś nową ideę, bo rozumiem, że mimo wszystko dla kogoś może to być nowe. Oczywiście, gender zmienia społeczeństwo - jeśli kobiety będą chciały podejmować inne decyzje niż te tradycyjne, wchodzić w inne role niż te tradycyjne, to dla wielu osób, które mają niskie poczucie własnej wartości - będzie to zagrożeniem. Ale kobiety nie mogą być traktowane gorzej tylko dlatego, że urodziły się kobietami. (Sawczenko, 2016)

Zwłaszcza w obliczu zmiany partii rządzącej dyskurs kościelny zaczął powoli zawłaszczać inne przestrzenie dyskursu, między innymi związane z kwestią przestrzegania praw obywatelskich, z wartością badań naukowych, czy z zakazem aborcji:

PiS rekomendował obcięcie planowanego budżetu RPO o 7 mln złotych i zapowiada, że pieniądze otrzyma Instytut Pamięci Narodowej. Poseł Arkadiusz Mularczyk argumentował, że Sejm nie będzie płacił na gender. Problemem dla PiS okazała się dr Sylwia Spurek, Zastępczyni Rzecznika Praw Obywatelskich ds. Równego Traktowania.

D: Jak pani odebrała ten personalny atak?

dr Sylwia Spurek: Jest mi przykro, że stałam się „bohaterką” tej komisji, choć przedmiotem posiedzenia miał być budżet RPO. To prawda - jestem „panią od gender”, wykładałam na Uniwersytecie Warszawskim i w Polskiej Akademii Nauk. Od dawna zajmuję się kwestiami równego traktowania ze względu na płeć i uważam, że one są bardzo ważne. (Ciastoch, 2016)

Ostrej krytyki doczekała się też sama idea poprawności politycznej, której przestrzeganie jest oczywistością w całej Europie:

Polityczna poprawność stała się narzędziem dyskryminacji. Co z tego, że pojawiła się, by położyć kres dyskryminacji, skoro dziś sama stała się tej dyskryminacji narzędziem. Po prostu jak każdy przykład inżynierii społecznej, ciąży w stronę dyktatury. Jak każda dyktatura, tak i ta daje władzę w ręce ludzi miernych, przez nikogo nie wybranych - prawo do kontrolowania naszych umysłów. (Cieślik, 2015)

W Polsce poprawność polityczna jest nadal uznawana za narzędzie dyskryminacji (sic!) patriotycznej, katolickiej większości. W dyskursie nie mamy już jednak do czynienia z fazą ostrego konfliktu z końca 2013 roku. Obie strony zostały wprawdzie przy swoich opiniach, ale zainteresowanie pojęciem gender wyraźnie spadło, natomiast skutkiem zaistniałej sytuacji - owej wielości pojawiających się 
definicji, opinii, wyjaśnień - jest wzrost ogólnego poziomu wiedzy i społecznej świadomości dotyczącej płci społeczno-kulturowej.

\section{Podsumowanie}

Na podstawie analizy zebranych wypowiedzi można wnioskować, że mamy do czynienia z różnymi sposobami rozumienia, w gruncie rzeczy, tych samych zjawisk i z różnymi sposobami konceptualizowania interesów różnych grup społecznych. W poniższej tabeli przedstawiono zestawienie kategorii dyskursu liberalnego związanych z kwestiami płci społeczno-kulturowej oraz odpowiadające im kategorie dyskursu konserwatywnego.

Tabela 1. Te same zjawiska - różne rozumienia

\begin{tabular}{|c|c|}
\hline Kategorie dyskursu liberalnego & Kategorie dyskursu konserwatywnego \\
\hline $\begin{array}{l}\text { Związki partnerskie, bardzo ważna sfera nasze- } \\
\text { go życia: prawa człowieka, prawa obywatelskie; } \\
\text { możliwość dziedziczenia i wspólnego rozliczania } \\
\text { się z podatków; problem do rozwiązania. }\end{array}$ & $\begin{array}{l}\text { Małżeństwa homoseksualne, sprawa sumienia, } \\
\text { obrona praw tradycyjnej rodziny, otwarcie drogi do } \\
\text { kolejnych żądań, podkopanie instytucji małżeńst- } \\
\text { wa jako fundamentu społecznego ładu; rewolucja } \\
\text { obyczajowa, niszczenie duchowości i moralności. }\end{array}$ \\
\hline Homofobia. & $\begin{array}{l}\text { Sprzeciw wobec powierzania na wychowanie dzie- } \\
\text { ci parom lesbijsko-gejowskim. }\end{array}$ \\
\hline Walka z mową nienawiści. & Demagogia/dyktat poprawności politycznej. \\
\hline Działacze na rzecz równych praw. & Lobby homoseksualne, homoseksualni aktywiści. \\
\hline Problem wielu obywateli. & $\begin{array}{l}\text { Wypowiadanie się w imieniu większości: polscy } \\
\text { politycy, polskie społeczeństwo, większość posłów. }\end{array}$ \\
\hline
\end{tabular}

Źródło: opracowanie własne

Samemu pojęciu gender również przypisuje się skrajnie różne znaczenia w dyskursie konserwatywnym i liberalnym. W ujęciu liberalnym gender to:

(...) z angielskiego płeć kulturowa, która, w odróżnieniu od płci biologicznej (sex), wg najprostszej definicji, jest konstruowana społecznie. Gender więc, to zespół cech, atrybutów, postaw, ról społecznych, przypisany mężczyźnie i kobiecie przez szeroko rozumianą kulturę. O tym, czy ktoś jest mężczyzną czy kobietą, nie decyduje sama budowa narządów płciowych, ale przede wszystkim kultura (we współczesnych teoriach dotyczących gender, także płeć biologiczna jest konstruktem społecznym), która wyznacza kobiecie i mężczyźnie odmienne role płciowe, a one stają się wzorcami zachowań wymaganymi przez społeczeństwo. Wyznaczanie ról płciowych opiera się na podkreślaniu różnicy płci, poprzez podział pracy, legitymizację pewnej pozycji społecznej, seksualizację, i bazuje na przekonaniu, że społeczne różnice ról płciowych są niezmienne (patrz: posłowie i posłanki pra- 
wicy). Nauka o gender wykazała, że jego definicja zmienia się w zależności od warunków społecznych, politycznych, kulturowych. Gender nie jest stały, więc i my możemy wpływać na jego kształt, choćby w celu zniesienia nierówności płci. (Wilk, 2012)

Podczas gdy w dyskursie konserwatywnym mówi się niemal to samo, ale prześmiewczo, z wyraźną nutą wrogiej ironii:

Gender (tłumaczone jako „rodzaj” bądź w ogóle nietłumaczone) - nowomodne określenie płci, w przeciwieństwie do staroświeckiego „sex” określające ją jako zjawisko kulturowe, nie biologiczne. Ujmuje się w tym epokowe odkrycie feminizmu, że kobieta bynajmniej nie rodzi się kobietą, ale staje się nią w procesie wychowania. To, że wydaje się inaczej zbudowana i że według powszechnego stereotypu w przeciwieństwie do mężczyzny rodzi dzieci, nie jest bynajmniej biologiczną determinantą, ale wmówieniem ze strony patriarchalnego, opresyjnego społeczeństwa. Przyznać trzeba, iż budowana przez wieki patriarchalna zmowa, która zdołała stłamsić całe pokolenia kobiet, okazuje się silna i wciąż nie brak faszystów, którzy ośmielają się publicznie odkrycie feministek negować, a nawet wyszydzać. Niemniej miliardy wydawane w bogatych krajach na kultywowanie doktryny w ramach licznych wyspecjalizowanych uniwersytetów i instytutów muszą w końcu przynieść oczekiwany skutek; na razie pozwalają na wygodne życie legionom działaczek od wyrównywania praw. (Ziemkiewicz, 2009: 61)

W wypowiedziach konserwatywnych polityków jest obecna mowa nienawiści, czyli, definiując za L.M. Nijakowskim,

(...) używanie języka w celu znieważenia, pomówienia lub rozbudzenia nienawiści wobec pewnej osoby, grupy osób lub innego wskazanego przez mówcę podmiotu, przy czym „szkalowanie tej grupy może mieć - i najczęściej ma - charakter ukryty (...) trudno jest jednoznacznie wykazać, zwłaszcza w postępowaniu sądowym, że dany komunikat szkaluje określoną grupę lub wzywa do wrogich wobec niej działań. (Nijakowski, 2006: 61)

Uznając jednak za Judith Butler, że „tym, co czyni mowa nienawiści, jest ustanowienie podmiotu w pozycji podporządkowania” (Butler, 2010: 28), możemy dostrzec, iż pełne nienawiści słowa utrwalają pozycje dominacji. Wiele tego typu sugestii odnajdziemy w przytoczonych wypowiedziach Jarosława Gowina. Jest to mowa nienawiści w wersji „light”. Przy czym podkreślić należy, że jest ona nawet bardziej niebezpieczna niż otwarta, jawna mowa nienawiści, ponieważ jest niejednoznaczna i ukryta, a zatem nie otwiera możliwości krytycznej reakcji, która to jednocześnie zadałaby mowie nienawiści porażkę. Czy w takim razie poprawność polityczna jest równie niebezpieczna jak mowa nienawiści, pozwalając tej drugiej „zejść do podziemia”, działać „podskórnie”, w sposób na pierwszy rzut oka niewidoczny? 
Jeszcze 10 lat temu w odniesieniu do osób homoseksualnych często z ust głównych aktorów sceny politycznej padały określenia takie jak „dewiant” lub „zboczeniec". Obecnie język konserwatywnych polityków jest dużo łagodniejszy. Nie pojawiają się już tak wyraziste wypowiedzi na przykład w sprawach kobiet, jak wypowiedź Mariana Piłki z 2005 roku, który stwierdził, że kobiety powinny robić „kariery” żon i matek, gdyż w przeciwnym razie będą niespełnione i zazdrosne o „sukcesy” innych kobiet na tym polu, podżegał jednocześnie „normalne” kobiety do nienawiści wobec feministek:

Celem tzw. wyzwolenia kobiet ma być ich kariera i awans społeczny. W ich imię mają poświęcić rolę żony i matki. I wiele poświęca. Ale kariera, podobnie jak i pieniądze, tylko do pewnego stopnia daje zadowolenie. Później pozostaje pustka, zgorzknienie, uczucie niespełnienia, zazdrość wobec tych kobiet, które mają rodziny i często nienawiść wobec nich. Aby zasłonić narastające poczucie pustki, feministki próbują wydłużyć wiek emerytalny. Wypełnianie roli żony i matki nie musi stać w sprzeczności z karierą zawodową. Bóg dał kobietom dłuższe życie niż mężczyznom. Po odchowaniu dzieci kobiety mogą realizować się zawodowo i społecznie. (Piłka, 2004)

$\mathrm{Na}$ tego typu wypowiedzi nie ma już przyzwolenia w sferze publicznej. Nieco inaczej jest z wypowiedziami homofobicznymi w polskim dyskursie politycznym - przyzwolenie także jest coraz mniejsze, ale mimo wszystko takie wypowiedzi nadal się pojawiają $\mathrm{w}$ formach bardzo obraźliwych, często zdradzających skrajną ignorancję i niewiedzę osób je wygłaszających. Idealnym przykładem jest tekst napisany na Facebooku przez Marka Jakubiaka - właściciela browaru produkującego piwo Ciechan, a następnie posła partii Kukiz'15 - do boksera Dariusza Michalczewskiego:

\section{Życzę ci mamusi z fujarka zamiast piersi. Będziesz miał co ssać.}

Po tych słowach z zakupu produkowanego przez niego piwa zaczęły rezygnować kolejne kluby i pojedynczy klienci, twierdząc, że wypowiedź Jakubiaka była homofobiczna, ale nadal nie przeszkodziło mu to w robieniu kariery politycznej.

Podobny efekt wywołała kontrowersyjna wypowiedź wspomnianego już Jana Tomaszewskiego - byłego bramkarza reprezentacji Polski, obecnie posła PiS - który powiedział publicznie, że nie wyobraża sobie, by mógł dzielić szatnię z gejem, i wyraził swoje poparcie dla polityki, jaką wobec homoseksualistów uprawia Władimir Putin, co spotkało się z szerokim odzewem ze strony środowisk sportowych, ale także nie wykluczyło go z polityki. 
Na zakończenie warto przytoczyć jeszcze słowa prof. Magdaleny Środy na temat istoty poprawności politycznej:

Jeśli ludzie nie czują miłości bliźniego, powinni chociaż zachować pozory przestrzegania jej zasad. I temu służy poprawność. By nie ranić mową. Jeśli śmieciarz czuje, że nazwa jego zawodu brzmi lekceważąco i wolałby, by nazywano go „operatorem ekologicznym”, to dlaczego nie? (...) Wracając do mowy nienawiści, nie można nikogo penalizować. Najlepiej byłoby otaczać ostracyzmem ludzi, którzy po prostu nie umieją się zachować. Tak samo jak nie przyjmujemy „na salony” kogoś, kto puszcza bąki, a nos wyciera w rękaw zamiast w chusteczkę. (...) niektórzy to kupują, bo puszczanie bąków wydaje się im niezwykłe. Takie oryginalne i rzadkie! (Kurc, 2009)

Czym zatem jest poprawność polityczna - politycznym kagańcem czy brakiem przyzwolenia na publiczne „puszczanie bąków”? Wszystko zależy od przyjętej perspektywy. Jedno jest pewne - kwestia płci społeczno-kulturowej jest polityczna. Sposób definiowania zjawisk i nazywania procesów wyznacza granice władzy, w związku z tym dyskredytowanie członków pewnych grup służy postawieniu ich w pozycji podporządkowania. Przytoczone wypowiedzi są świadectwem tego, że na polskiej scenie politycznej mamy do czynienia z nieustającą walką o to, który dyskurs - konserwatywny czy liberalny - uzyska dominującą pozycję. Kwestie gender stają się w tym kontekście przedmiotem zawłaszczenia poprzez nadawanie im odpowiednich znaczeń - zgodnych ze światopoglądem i opcją polityczną danego mówcy. Jednocześnie jest to walka o „rząd dusz” - o możliwość kontrolowania umysłów wyborców i niewątpliwie związaną z tym władzę.

\section{Bibliografia}

Bratkowska M. (2013), Wszyscy jesteśmy trochę homo, Wprost, nr 29.

Bruchwald A. (2013), Gender - objaw ludzkiej pychy. Wywiad z prof. Andrzejem Półtawskim i Wandą Półtawską, Nasza Polska, http://wolnapolska.pl/index.php/Wiara/2013062417261/gender-objaw-ludzkiej-pychy-wywiad-qnaszej-polskiq-z-prof-andrzejem-potawskim-i-wand-potawsk/ menu-id-224.html, dostęp: 30.04.2016.

Burnetko K. (2013), Co się stało księdzu Oko, Polityka, nr 31.

Butler J. (1997), Excitable Speech: A Politics of the Performative, New York-London.

Ciastoch M. (2016), PiS karze za gender, Newsweek, http://polska.newsweek.pl/pis-obcina-pieniadze-rzecznikowi-praw-obywatelskich-przez-gender,artykuly,376832,1.html, dostęp: 5.03.2016.

Cichobłazińska A. (2013), Gender - ideologia totalitarna. Wywiad z ks. Dariuszem Oko, Niedziela, http://www.niedziela.pl/artykul/106423/nd/, dostęp: 30.04.2016.

Cieśla J. (2013), Czy mózg ma płeć?, Polityka, numer specjalny, nr 4.

Cieślik M. (2015), Gender wygrywa wojnę ze słownikiem i rozsądkiem, Raport, Wprost, http://www. wprost.pl/ar/512215/Raport-Wprost-Gender-wygrywa-wojne-ze-slownikiem-i-rozsadkiem/, dostęp: 5.03.2016. 
Czyżewski M. (2010), W stronę dyskursu publicznego, [w:] M. Czyżewski, S. Kowalski, A. Piotrowski (red.), Rytualny chaos. Studium dyskursu publicznego, Warszawa, s. 49-119.

Czyżewski M., Franczak K., Nowicka M., Stachowiak J., (red.) (2014), Dyskurs elit symbolicznych. Próba diagnozy, Warszawa.

Czyżewski M., Kowalski S., Piotrowski A. (red.) (2010), Rytualny chaos. Studium dyskursu publicznego, Warszawa.

Gracz A. (2013), Samobójstwo zachodu. Wywiad z kard. Robertem Sarahem, przewodniczącym Papieskiej Rady Cor Unum, Nasz Dziennik, http://www.naszdziennik.pl/mysl/50502,samobojstwo-zachodu.html, dostęp: 30.04.2016.

Grochal R. (2011), Związki? Nigdy! Interview with J. Gowin, Gazeta Wyborcza, http://wyborcza. pl/1,75478,9716535,Gowin_Zwiazki_Nigdy.html, dostęp: 18.01.2012.

Jarkowiec M. (2013), Gej też twardziel, Wprost, nr 32.

Jędrzejczyk M. (2013), Gender groźniejsze od marksizmu. Wywiad z ks. abp. Henrykiem Hoserem, przewodniczącym Zespołu Ekspertów ds. Bioetycznych Konferencji Episkopatu Polski, ordynariuszem warszawsko-praskim, Nasz Dziennik, http://www.naszdziennik.pl/wiara-kosciol-w-polsce/24344,gender-grozniejsze-od-marksizmu.html, dostęp: 30.04.2016.

Kaczyński chce walczyć o godność kobiet w Polsce (2011), Wirtualna Polska, http://wiadomosci. wp.pl/title,Kaczynski-chce-walczyc-o-godnosc-kobiet-w-Polsce,wid,13582633, wiadomosc. html?ticaid=1dc67, dostęp: 15.01.2012.

Kopciewicz L. (2011), Nauczycielskie poniżanie. Szkolna przemoc wobec dziewczat, Warszawa.

Kopiński M. (2014), Dość już gender histerii. Wywiad z Agnieszką Kozłowską-Rajewicz, Polska Times, http://www.polskatimes.pl/artykul/3318778, agnieszka-kozlowskarajewicz-dosc-juz-gender-histerii-wywiad,id,t.html, dostęp: 5.03.2016.

Kośmiński P. (2014), Kaczyński opowiada o osobach „tranwers..., bardzo dziwnych.” Dostał broszury i zaproszenie na szkolenia, Gazeta Wyborcza, http://wyborcza.pl/1,76842,16569473,Kaczynski_ opowiada_o_osobach_tranwers___bardzo.html, dostęp: 16.10.2014.

Kurc M. (2009), Czas na aspiracje polityczne. Interview with Magdalena Środa, Portal Gej\&Les "Inna Strona," http://www.innastrona.pl/magazyn/wywiady/prof-magdalena-sroda.phtml, dostęp: 18.01.2012.

Meller A. (2011), Wywiad posła Roberta Wegrzyna dla portalu konserwatyzm.pl, http://konserwatyzm.hostingasp.pl/artykul/739/wywiad-posla-roberta-wegrzyna-dla-portalu-konserwatyzmpl, dostęp: 30.04.2016.

Moscovici S. (2000), Social Representations: Explorations in Social Psychology, Cambridge.

Nałęcz M. (2015), Synod biskupów: W relacji końcowej znajduje się krytyka gender. Słowa o rozwodnikach bywają niejasne, PolskaTimes, http://www.polskatimes.pl/artykul/9026879,synod-biskupow-w-relacji-koncowej-znajduje-sie-krytyka-gender-slowa-o-rozwodnikach-bywaja-niejasne,id,t.html, dostęp: 5.03.2016.

Nijakowski L.M. (2006), Analiza dyskursu na temat mniejszości narodowych i etnicznych w polskich mediach. Aspekty teoretyczne i przykłady, Racjonalista, www.racjonalista.pl/pdf.php/s,4820, dostęp: 15.01.2012.

Nizinkiewicz J. (2014), Ideologia gender nie uznaje Boga, rozmowa z biskupem Tadeuszem Pieronkiem, byłym przewodniczącym Kościelnej Komisji Konkordatowej,, http://polska.newsweek. pl/kosciol-a-gender-czym-jest-gender-newsweek-pl,artykuly,278350,1.html, dostęp: 5.03.2016.

Oko D. (2013), Genderyzm to straszne zagrożenie. Sipowicz: grupa biskupów stworzyła sztucznego wroga. Zapis dyskusji w programie „Kropka nad i” dated 23.12.2013, http://www.tvn24.pl, dostęp: 30.04.2016. 
Olczyk E. (2011), Chca nam przyprawić gębę. rozmowa z Wandą Nowicką, Rzeczpospolita, http:// www.rp.pl/artykul/731930.html?print=tak\&p=0, dostęp: 17.01.2012.

Piłka M. (2004), Nienawiść do kobiet, Niedziela, nr 42, http://niedziela.pl/artykul_w_niedzieli. php?doc=ed200442\&nr=112, dostęp: 18.01.2012.

Piłka M. (2011), Upadek Europy, Salon24. Niezależne forum publicystów, 26.10., http://lubczasopismo.salon24.pl/glosogospodarce/post/356566,upadek-europy, dostęp: 17.01.2012.

PO, PiS, PSL i PJN mówią projektowi SLD ws. związków partnerskich: "Nie!”, (2011), Newsweek, http://m.newsweek.pl/polska,po-pis--psl-i-pjn-mowia-projektowi-sld-ws--zwiazkow-partnerskich---nie-,76838,1,1.html, dostęp: 15.01.2012.

Prekiel P. (2011), Szanse Palikota. rozmowa z R. Biedroniem, Przegląd Socjalistyczny, http://www. przeglad-socjalistyczny.pl/wywiad-tygodnia/675-biedron, dostęp: 30.04.2016.

Priorytet - ustawa o związkach partnerskich (2011), Gazeta Wyborcza, http://wyborcza. pl/1,76842,10530666,Biedron__priorytet_ustawa_o_zwiazkach_partnerskich.html, dostęp: 30.04.2016.

Rogojsz Ł. (2014), Gender, czyli dziewczynka do bicia, Newsweek, http://polska.newsweek.pl/gender-kontrowersje-spory-gender-studies-zalozenia-studia-genderowe-plec-kulturowa-newsweek-pl,artykuly,278337,1.html, dostęp: 5.03.2016.

Sawczenko A. (2016), Gender jest potrzebne w szkolnych podręcznikach. Rozmowa z J. Piotrowską, PolskaTimes, http://www.polskatimes.pl/artykul/9291392,joanna-piotrowska-gender-jest-potrzebne-w-szkolnych-podrecznikach,id,t.html, dostęp: 5.03.2016.

Schopenhauer A. (2010), Erystyka, czyli sztuka prowadzenia sporów, Kraków, s. 47-52.

Śledzińska-Simon A. (ed.), (2010), Prawa osób transseksualnych. Rozwiązania modelowe a sytuacja $w$ Polsce, Warszawa.

Smolińska I., Bratkowska M. (2013), Uwięzieni w obcym ciele, Wprost, nr 7.

Sowa A. (2013), Pytania o homozwiązki, Polityka, numer specjalny, nr 7.

Środa M. (2013), Homo poza normą?, Wprost, $\mathrm{nr} 7$.

Trzecia płeć, (2013), Polityka, nr 35.

Tym S. (2013), Pies czyli kot. Zielona Antarktyda, Polityka, nr 32.

Van Dijk T.A. (2001), Critical discourse analysis, [w:] D. Tannen, D. Schiffrin, H. Hamilton (reds), Handbook of Discourse Analysis, Oxford, s. 352-358.

Van Dijk T.A. (2009), Critical discourse studies; A sociocognitive Approach, [w:] R. Wodak, M. Meyer (red.), Methods of Critical Discourse Analysis, London, s. 62-86.

Wesołowski W. (2013), Gender wchodzi do szkół i przedszkoli. Rozmowa z biskupem Markiem Mendykiem, przewodniczącym Komisji Episkopatu polski ds. Wychowania Katolickiego, Niedziela, http://www.niedziela.pl/artykul/6352/Gender-wchodzi-do-szkol-i-przedszkoli, dostęp: 30.04.2016.

Wilk A. (2012), Studia nad gender, http://www.feminoteka.pl/readarticle.php?article_id=75, dostęp: 16.01.2012.

Wrzos-Lubaś M. (2011), Stworzę prawo o określaniu płci. rozmowa z Anną Grodzką, Polska Times, http://www.polskatimes.pl/artykul/458800,anna-grodzka-stworze-prawo-o-okreslaniu-plci,id,t.html, dostęp: 16.01.2012.

Ziemkiewicz R. (2009), W skrócie, Lublin.

Zwolennicy ideologiigender atakują. Nie omijają nawet „royal baby”(2013), http://niezalezna.pl/43994-zwolennicy-ideologii-gender-atakuja-nie-omijaja-nawet-royal-baby, dostęp: 30.04.2016. 
